\title{
Cat Image in Ex-Libris Design
}

PhD. Ezgi Karaata Doğuş University, Faculty of Fine Arts and Design, Department of Graphics ekaraata@dogus.edu.tr

Full Length Paper Accepted 10 January 2018

\section{Abstract}

Ex-libris is a personal art form that is located in the book lover's library, inside the cover of the book that he chooses and reads fondly. While reflecting an image which gives importance to the book owner's life, it also establishes a loyalty bond between the book and the owner. Many people who are book lovers have also been close friends with cats. Because they want to carry this friendship into the ex-libris which will take place in the books they love, the image of the cat is quite common in the art of ex-libris. In this study, the results of scanning approximately 290 ex-librises, including cat images at the Frederikshavn Digital Ex-libris Museum, has been examined according to years, countries and techniques.

Key words: Ex-libris, Cat, Art, Graphic, History, Culture 


\section{Introduction}

Ex-libris is a form of artwork that symbolically represents the owner of a book. A Latin expression, the ex-libris are small postcards that reflect the owner's personality, upbringing, social position, profession, knowledge, past and even vision. According to the definition by Professor Hasip Pektaş, "The ex-libris are small-sized original works that book lovers attach to the inner cover of their books and feature the owner's name and pictures with various subject matters. They are the calling cards or deeds of books." (Pektaş, 2017, s. 11) They are designed according to the book owner's demands and include images the owner likes. As made-to-order works, they depend on the tastes and life priorities of the owner. People who know the owner well can better make out the connection of the images on an ex-libris with the owner and their meaning. The ex-libris artist endeavors to give a message about the book owner and present his art, and create a commendable artwork. In his article titled "Bir Sanat Dalı Olarak Ekslibris", Professor Sıtkı M. Erinç analyzes ex-libris based on their subject matter, and says, "It should be a work of art, symbolize the technical skills, artistic abilities and style of the artist, i.e. indicate to his character. It should establish a relationship between the artist and the book owner. It should involve the universal symbols of print, evoke aesthetic consideration in the receiver, and be aesthetically pleasing and beautiful.” (Erinç, 1996, s. 71-72) As animals, cats are beautiful in a way that inspires awe, aesthetically pleasing in anatomy and interest in character. Since their domestication, an everlasting bond has been established between cats and people throughout the ages. Therefore, cats have always appeared in the artworks of different cultures. Images of cats are observed in various branches of art, and they are also depicted in ex-libris. Book lovers, artists and designers have long included cats in their ex-libris as their friends. This paper analyzes the relationship between the cat image and ex-libris in the screening method and is based on the results of literature and image screening.

\section{Brief History of Ex-Libris in the World and Turkey}

Ex-libris emerged as a graphic requirement; however, aesthetic concerns involved in ex-libris make it original and bring it together with people at its closest. (Pektaş, 2017, s. 11)

While manuscripts belonged to the clergy and princes at first, the invention of printing press increased the number of books, which in turn became easily accessibly to the educated bourgeoisie, lower class merchants and other wealthy classes. Readers exchanged books and borrowed books were intentionally not returned at times. Apart from book exchanges, book theft 
reached such a disconcerting scale that it became the bane of the Middle Ages and the Renaissance. Therefore, Pope Benedict XIV had to issue a papal bull in 1752 and announced that book thieves would be excommunicated.

An estimable Renaissance book includes maledictions, which begins with the words "My Master's name above you see, take heede therefore you steale not mee", and there is an inscription at the San Pedro monastery in Barcelona that starts with the words "For him that steals, or borrows and returns not, a book from its owner" (Manguel, 2001, s. 284) These notes on books are intended to prevent book theft to some extent. An attempt was made to protect book ownership through the ex-libris and solve the problem of book theft and losses in book exchanges. As is seen, ex-libris was created to provide for an important historical necessity. Devised as a way to prevent book loss, ex-libris was a way to form a connection between book owners and books as entities.

Special notes like footnotes have been used below the scripts on papyri and leather since the invention of writing and the times when thoughts were carved in stone, and as this tradition gained popularity after the invention and proliferation of paper, continued with markings on the foot of papers.

"Research indicates that the first example of ex-libris is seen on a light blue tile in the library of Amenhotep III in Egypt circa 1400 BC."(Pektaş, 2017, s. 13)

A scribe during the 19th Egyptian dynasty circa 1300 BC wrote the following encomium on his profession, which can be classified as one of the earliest examples of ex-libris:

"Be a scribe! Engrave this in your heart

So that your name might live on like theirs!

The scroll is better than the carved stone.

A man has died: his corpse is dust,

And his people have passed from the land.

It is a book which makes him be remembered

In the mouth of the speaker who reads him.” (Manguel, 2001, s. 218)

A large number of mercantile professions emerged as commerce developed in the late 8th century BC, especially in coastal countries, and in an attempt to set themselves apart from other traders, these merchants selected what we today call "emblems" as their identification marks. Ceramicists marked their ceramics, bricklayers marked their walls, and paper makers marked their papers with their seals. These marks that identify the owner functioned as a sort of deed for the merchants, and, therefore, have similarities with the ex-libris. 
The first animalistic seals found in excavations in Anatolia date back to the 7400 BC. Layers recovered in excavations of various mounds have yielded seals from the Ottoman, Seljuk, Byzantine, Roman, Hellenistic, Phrygian, Hittite periods, the Early Bronze Age and the Chalcolithic ages, respectively. (Güney, 2014)

Sympathetic and mostly religious figures from the Chalcolithic Age, dated between 5000 and $3000 \mathrm{BC}$, were found in the mounds of several cities including Mersin, Konya, Malatya, Gaziantep, Denizli, Çorum, and Elazı̆̆. The recovered seals and clay bullae indicate that there was substantial commercial activity during the period. Seals with sympathetic and mostly religious figures were made from raw materials such as soapstone, diorite and serpentine. A large number of earthenware and stoneware seals have been discovered in settlements in the Euphrates region. (Akurgal, 2005)

"A simple crest hand painted on wood and an ex-libris of the owner's statement in Germany from the third quarter of the 15th century AD are the first true examples of ex-libris.” (Okur, 2013, s. 41)

Books were a testament to the social positions of families in the 18th century France. Regarded as a part of family fortune, ever-growing private libraries were passed down from generation to generation in the nobility. When the Count of Hoym, a respected book lover of the period, drew Cicero's Orations from the crowded shelves of his library, he saw it as a singular, original object, binded according to his wishes and imprinted with his family crest in gold letters, instead of a copy among thousands. (Manguel, 2001, s. 279) The nobility and wealthy bourgeoisie preferred that the books in their libraries, which were among the suitable spaces for their social station in their chateau, reflect their status and personality, bear some aspects of themselves and be original objects and, to that end, they demanded artists' work and paid a fee. The first ex-libris thusly entered the first pages of books, applied in various drawing techniques. Even famous painters like Dürer, Picasso and Klee did ex-libris work. It should be remembered that, as a work of art, ex-libris must serve two functions: aesthetic consideration and delivering a message. (Okur, 2013, s. 43)

Ottoman manuscripts and printed books had seals, miniatures and engravings on their first pages, which may be regarded as a sign of ownership, albeit not ex-libris proper. The use of seals was very popular among the public, tradespeople, the gentry, ulema and statesmen. Depending on the financial status of seal orderer, seals were carved in minerals like gold, silver, brass and copper or precious stones like onyx, emerald, ruby, turquoise, jade and pearl. In manuscripts, book title and 
the orderer's name were recorded in the inner cover, which was called zahriye. A record of possession named temellük kaydı was kept for Ottoman manuscripts. They were placed on page $1 / \mathrm{a}$ of the book. "Although seals do not classify as ex-libris, they served the same function as the crests of the book owner with their original calligraphic structure.” (Pektaş, 2017, s. 29) An examination of manuscripts from the Ottoman period shows that seals were used as signs of ownership. When books were exchanged, the name of the new owner or organization was sealed on the same page.

There are examples of ex-libris in certain books on Turkey, purchased at auctions in the west. A book on the Ottoman history, printed in 1777 and purchased in Germany, is currently located at the National Library and has an ex-libris. Several books on the Ottoman Empire from the library of Henry M. Blackmer, purchased by the Ministry of Culture at the Sotheby auction in London in 1989, have ex-libris as well. Professor Hasip Pektaş founded the Ex-Libris Society in Turkey in 1997. Thanks to the establishment, artists and designers in Turkey have been taking more interest in ex-libris. Renamed the Ex-Libris Society of Istanbul in 2008, the society has organized a large number of competitions, exhibitions and workshops and promoted ex-libris at local and international conferences. (Pektaş, 2017, s. 29-31)

\section{Cat Image in Ex-Libris Design}

'The smallest feline is a masterpiece.' — Leonardo da Vinci

Cats have been featured in the artworks of different cultures for their aesthetic build and interesting character. They are the only domesticated species of the feline family. Cats originated in Abyssinia. They were imported to Egypt around $2200 \mathrm{AD}$, and entered domestic life. Cats represented Egyptian deities of music, love and beauty. Domesticated cats were mentioned in a work written in Sanskrit 2000 years ago. (Aysoy, 1954, s. 42) The reason cats were regarded as goddesses in Egypt is that they protected wheat from mice in granaries and wheat fields.

In 1233, Pope Gregory IX issued a decree in Catholic Vatican and announced that Satan sometimes disguised itself as a cat, and Christians killed the cats in their homes and on the streets. The Black Plague broke out in Europe after this massacre and some 100 million people perished. The cat massacre escalated in the 1400 s during the reign of Pope Innocent VIII, and lasted until the 1750 s from France to Belgium.

Cats have had their friends and foes in every nation throughout history. Richelieu, Colbert, Montaigne, Ballay, Locke, Chateaubriand, Baudelaire, 
Victor Hugo, Gautier, Maupassant, Alexsandre Dumas, Loti, Georges Clemenceau, D. Lloyd George, Hemingway, Matisse, Picasso, Dali, and Jean Cocteau are among cat loving thinkers, poets, writers, clergymen and painters. (Aysoy, 1954, s. 40-41)

People acted warmly to cats, showed compassion and were nice to them in the East throughout history. As a result, a large number of eastern artworks feature cats.

For this paper, the ex-libris from the Frederikshavn Art Museum and Exlibris Collection were screened on the museum website (art-exlibris.net). In 2012, Foundations King Christian and Roblon contributed to the establishment of the comprehensive art-exlibris.net digital webpage, which received 4,500 visitors in its first six months and more than 500,000 visitors so far. The page includes ex-libris examples from 51 countries and artists and collectors from 110 countries benefit from it. Top visitor countries are Germany, U.S.A. and Denmark. The collection was divided into periods from the 1700 s to the present day, and can perform queries on the artist name, owner name, subject, technique and period of the ex-libris. The museum runs on material and spiritual devotion, and has one of the largest collections in the world. (Pektaş, 2017, s. 133)

We have analyzed 289 cat figures found among 450,000 ex-libris, including in terms of country and technique. One cat figure generally involves one technique but, rarely, some works include two or even techniques. The tables below inventory the cat ex-libris, which were drawn by artists of various European countries.

According to an evaluation of the ex-libris in the Frederikshavn Art Museum and Exlibris Collection webpage designed across the world between 1900 and 2018, countries that use cat images the most in these years in a list of 15 ranks are as follows:

1. Germany - 44 items,

2. Czechoslovakia - 32 items,

3. Denmark - 28 items,

4. Poland - 24 items,

5. Austria- 17 items,

6. Russia, France - 14 items,

7. Belgium - 13 items,

8. Italy, Japan- 11 items,

9. Bulgaria - 8 items,

10. Hungary, Lithuania, Estonia - 7 items,

11. Australia, Ukraine- 6 items, 
EX- BR ST International Journal of Ex-libris / Vol.4 / Part 8

\begin{tabular}{|c|c|c|c|c|c|c|c|c|c|}
\hline \multirow[b]{2}{*}{ COUNTRY } & \multicolumn{9}{|c|}{ YEARS } \\
\hline & $\begin{array}{l}1900- \\
1930\end{array}$ & $\begin{array}{l}1930- \\
1960\end{array}$ & $\begin{array}{l}1960- \\
1980\end{array}$ & $\begin{array}{l}\text { 1980- } \\
1990\end{array}$ & $\begin{array}{l}1990- \\
2000\end{array}$ & $\begin{array}{l}2000- \\
2010\end{array}$ & \begin{tabular}{|l}
$2010-$ \\
2018
\end{tabular} & $\begin{array}{c}\text { UN- } \\
\text { KNOWN }\end{array}$ & TOTAL \\
\hline ARGENTINA & & & & & & 1 & & 1 & 2 \\
\hline ARMENIA & & & & & & & & & $\circ$ \\
\hline AUSTRALIA & & & 6 & & & & & & 6 \\
\hline AUSTRIA & & 1 & & 14 & & & & 2 & 17 \\
\hline BELARUS & & & & & & & & & $\circ$ \\
\hline BELGIUM & & & 3 & 1 & & 2 & & 7 & 13 \\
\hline BOSNIA-HERZE. & & & & & & & & & $\circ$ \\
\hline BRAZIL & & & & & & & & & o \\
\hline BULGARIA & & & & & & 8 & & & 8 \\
\hline CANADA & & & 1 & & & & & & 1 \\
\hline CHINA & & & & & & & & & $\circ$ \\
\hline CROTIA & & & & & & & & & o \\
\hline CZECH REPUBLIC & & 2 & 6 & 3 & 4 & 4 & 1 & 12 & 32 \\
\hline DENMARK & & 2 & 9 & 2 & 2 & 1 & & 12 & 28 \\
\hline ENGLAND & & & 1 & 1 & & & & 3 & 5 \\
\hline ESTONIA & & 1 & 1 & & & & & 5 & 7 \\
\hline FINLAND & & & 1 & & & & & 1 & 2 \\
\hline FRANCE & & 3 & . & & & 4 & & 7 & 14 \\
\hline GERMANY & & & 3 & 3 & 3 & 12 & 7 & 16 & 44 \\
\hline GREENLAND & & & & & & & & & $\circ$ \\
\hline HOLLAND & & & & & & & & 5 & 5 \\
\hline HONG KONG & & & & & & & & & $\circ$ \\
\hline HUNGARY & & 1 & 2 & & & & & 4 & 7 \\
\hline INDIA & & & & & & & & & o \\
\hline IRELAND & & & & & & & & & o \\
\hline ISRAEL & & 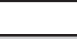 & & & & & & & $\circ$ \\
\hline ITALY & & 1 & . & 4 & 1 & 2 & 1 & 2 & 11 \\
\hline JAPAN & & & 3 & 4 & 2 & & & 2 & 11 \\
\hline LATVIA & & & & & & & & & $\circ$ \\
\hline LITHUANIA & & 1 & 2 & . & & 1 & & 3 & 7 \\
\hline LUXEMBURG & & & & 5 & & & & & 5 \\
\hline NEW ZEALAND & & & & & & & & & o \\
\hline NORWAY & & & . & & & & & & 0 \\
\hline POLAND & & & 2 & 6 & 1 & 3 & 1 & 11 & 24 \\
\hline ROMANIA & & & & & & & & 1 & 1 \\
\hline RUSSIA & & & 1 & 3 & 3 & 2 & & 5 & 14 \\
\hline SLAVONIA & & & & & & & & & $\circ$ \\
\hline SLOVAK REPUB. & & & & & & & & & $\circ$ \\
\hline SOUTH AFRICA & & & 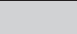 & & & & & & $\circ$ \\
\hline SOVIET UNION & & & 1 & & & & & & 1 \\
\hline SPAIN & & 2 & & 1 & & & & 1 & 4 \\
\hline SWEDEN & & & & & & & & 4 & 4 \\
\hline SWITZERLAND & & & & & & & & 1 & 1 \\
\hline TAIWAN & & & & & & & & & o \\
\hline TURKEY & & & & & & 2 & 3 & & 5 \\
\hline UKRAINA & & & & & 3 & 3 & & & 6 \\
\hline UNKNOWN & 1 & 1 & 1 & & & & & 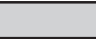 & 3 \\
\hline YUGOSLAVIA & & & . & & & & & 1 & 1 \\
\hline USA & & & & & & & & & $\circ$ \\
\hline TOTAL & 1 & 15 & 43 & 47 & 19 & 45 & 13 & 106 & 289 \\
\hline
\end{tabular}

Table 1: Periodical distribution of 289 ex-libris with cat images per country 
10. Luxemburg, the U.K., Turkey, the Netherlands - 5 items,

12. Spain, Sweden- 4 items,

13. Unknown - 3 items,

14. Finland, Argentina - 2 items,

15. The Soviet Union, Canada, Yugoslavia, Romania, Switzerland- 1 item.

The scarcest use of cat images in the ex-libris was during the period between 1900 and 1930. Only one ex-libris was designed in this time. The oldest exlibris in the global collection is one of unknown origin country titled "Woman and Book", created in 1921 in the P1 - line block technique by an unknown artist. (Image 1) A cat is seen on a woman lying down on a rather large book. The ex-libris depicts the time a woman spends with her book and her cat in the 1920s. The period with the largest number of cat images in ex-libris design is between 1980 and 1990. The collection includes 47 ex-libris with cat images from this decade.

Germany has the largest number of ex-libris with cats. Historically, the first proper ex-libris according to the current definition was a crest designed in Germany in the 15th century; therefore, it is natural for the same country to have the most ex-libris with cat images. Moreover, the first printing instrument was manufactured by Gutenberg in Germany. In terms of their subject, the ex-libris of Germany are led by images of book lovers with their cats as they read or a book and a cat as the two favorite objects. (Image 2) Following in the rankings are the cultural element of the town musicians of Bremen, personified cats, and realistic or humorous and, lastly, erotic narratives. It has been observed that these subject matters in the ex-libris designed in Germany are in common with the 289 ex-libris with cat images from around the world.

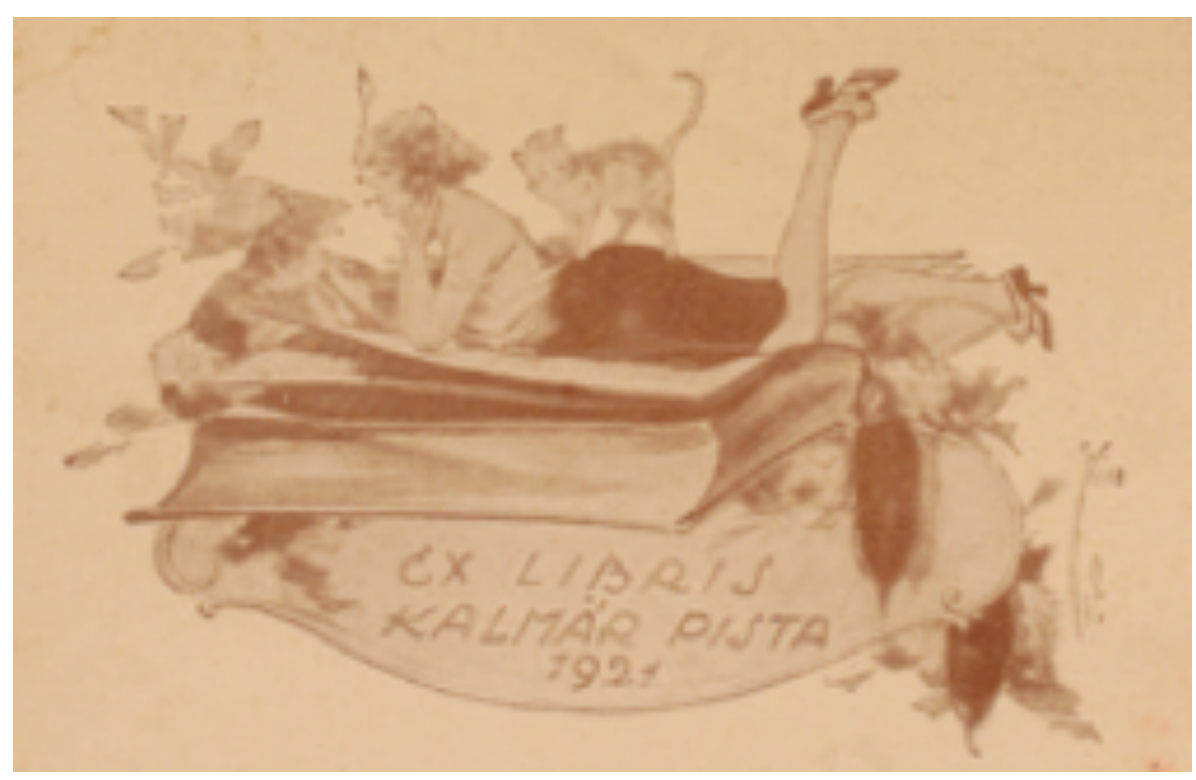

Image 1: “Woman and Book" ex-libris - 1921 


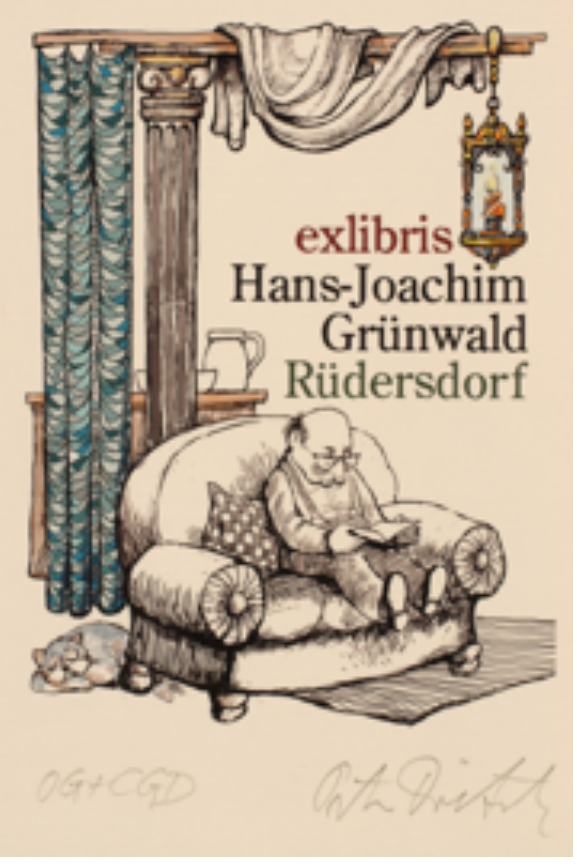

Image 2: "Anonymous" ex-libris - Germany, undated, Peter Dietzsch
Ex-libris designs with cat images are also encountered in the designs in our country. Although cat is a very popular animal in Turkey and has several local species like the Ankara Cat and the Van Cat, Turkey ranks 10th in the list of countries in terms of ex-libris designs with a cat image. The major cause of this is that ex-libris design is relatively unknown in Turkey but, after the establishment of the Ex-Libris Society in 1997, it has gained popularity among artists and designers and Turkey has taken place in the rankings as of 2000 and the number of cat ex-libris in Turkey increases with every passing year. (Image 3)

Another reason for cats to be depicted with books and libraries may be the long-standing hostility between cats and mice. In the past, the word kebikeç, which was thought to be "the sultan of bugs", was written on the borders of manuscripts to protect them from insects. It was believed that moths would be afraid of the kebikeç and avoid books. From this aspect, book thieves were identified with mice gnawing on and destroying books and cats were cast as the wardens of books and libraries in some of nearly 290 cat exlibris. (Image 4)

Abbreviations of ex-libris printing techniques in the table are expanded below.

$\mathrm{X}_{1}=$ Wood cut

$\mathrm{X}_{2}=$ Wood engraving

$\mathrm{X}_{3}=$ Linocut

$\mathrm{X}_{4}=$ Metal engraving

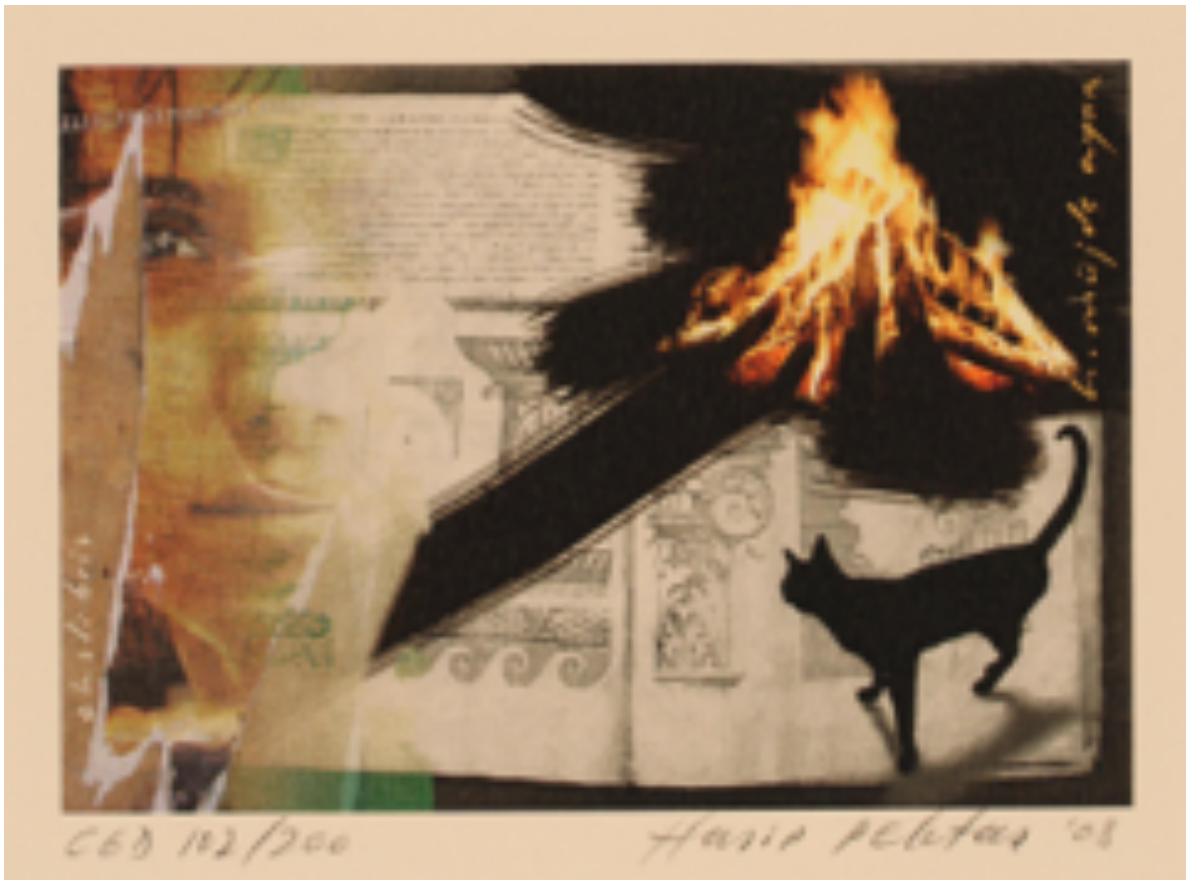

Image 3: "Anonymous" ex-libris - Turkey, 2008, Hasip Pektaş 
EX- BR ST International Journal of Ex-libris / Vol.4 / Part 8

\begin{tabular}{|c|c|c|c|c|c|c|c|c|c|c|c|c|c|c|c|c|c|c|}
\hline \multirow[b]{2}{*}{ COUNTRY } & \multicolumn{18}{|c|}{ TECHNIQUE } \\
\hline & $\mathrm{x}_{1}$ & $\mathrm{X}_{2}$ & $x_{3}$ & $\mathrm{X}_{4}$ & $x_{5}$ & $\mathrm{x} 6$ & $\mathrm{C}_{1}$ & $\mathrm{C}_{2}$ & $\mathrm{C}_{3}$ & $\mathrm{C}_{4}$ & $C_{5}$ & $\mathrm{C}_{7}$ & $P_{1}$ & P7 & P8 & CGD & $\mathrm{T}$ & $\begin{array}{c}\text { UN- } \\
\text { KNOWN }\end{array}$ \\
\hline ARGENTINA & & & & & & 1 & & & & & & & & & & & & \\
\hline \multicolumn{19}{|l|}{ ARMENIA } \\
\hline AUSTRALIA & & & & & & & & & 1 & & & & & & & & & \\
\hline AUSTRIA & 3 & 2 & 3 & & & & & 1 & 1 & & 1 & & & 3 & & & & 2 \\
\hline \multicolumn{19}{|l|}{ BELARUS } \\
\hline BELGIUM & & 4 & 1 & & & & & & 1 & & & & & & & 1 & & 6 \\
\hline \multicolumn{19}{|l|}{ BOSNIA-HERZE. } \\
\hline \multicolumn{19}{|l|}{ BRAZIL } \\
\hline BULGARIA & & 3 & & & & & & & 1 & & 1 & & & & & & & 4 \\
\hline CANADA & & & & & & & & & & & & & & & & & & 1 \\
\hline \multicolumn{19}{|l|}{ CHINA } \\
\hline \multicolumn{19}{|l|}{ CROTIA } \\
\hline CZECH REPUBLIC & & 5 & & & & & & & 8 & & & & & & & & 2 & 18 \\
\hline DENMARK & 1 & 2 & 1 & & & & & & 1 & & & & 3 & 2 & & & 1 & 18 \\
\hline ENGLAND & & 4 & & & & & & & & & & & & & & & & 1 \\
\hline ESTONIA & & 2 & 2 & & & & & & 1 & & & & & & & & & 4 \\
\hline FINLAND & & & & & & & & & & & & & & & & & & 2 \\
\hline FRANCE & & 3 & & & & & & & & & & & 1 & & & & & 11 \\
\hline GERMANY & 3 & 3 & 2 & & & & & 4 & 16 & 2 & 11 & & & 3 & & 5 & & 10 \\
\hline \multicolumn{19}{|l|}{ GREENLAND } \\
\hline HOLLAND & & 2 & 3 & 1 & 1 & & & & & & & & & & & & & \\
\hline \multicolumn{19}{|l|}{ HONG KONG } \\
\hline HUNGARY & 1 & 2 & 1 & & & & & 1 & 1 & & & & 1 & & & & & \\
\hline \multicolumn{19}{|l|}{ INDIA } \\
\hline \multicolumn{19}{|l|}{ IRELAND } \\
\hline \multicolumn{19}{|l|}{ ISRAEL } \\
\hline ITALY & & 4 & & & & 2 & & & 3 & 1 & & 2 & & & & & & 1 \\
\hline JAPAN & 9 & & 2 & 4 & & & & & & & & & & & & & & 2 \\
\hline LATVIA & & 1 & & & & & & & & & & & & & & & & \\
\hline LITHUANIA & & & 2 & & & & & & 2 & & 1 & & 2 & & & & & 1 \\
\hline LUXEMBURG & & & & & & & & 1 & & & & & 4 & & & & & \\
\hline \multicolumn{19}{|l|}{ NEW ZEALAND } \\
\hline NORWAY & & & & & & & & & & & & & & & & & & \\
\hline POLAND & 1 & 2 & 4 & & & & & 2 & & & & & 1 & 1 & 1 & 2 & 1 & 10 \\
\hline ROMANIA & & & & & & & & & 1 & & & & & & & & & \\
\hline RUSSIA & & 3 & 1 & & & & & & 5 & & & & & 1 & & & & 5 \\
\hline SLAVONIA & & & & & & & & & & & & & & & & & & \\
\hline SLOVAK REPUB. & & & & & & & & & & & & & & & & & & \\
\hline SOUTH AFRICA & & & & & & & & & & & & & & & & & & \\
\hline SOVIET UNION & & 1 & & & & & & & & & & & & & & & & \\
\hline SPAIN & & 1 & & & & & & & & & & & & & & & & 3 \\
\hline SWEDEN & & & & & & & & & & & & & & & & & & 1 \\
\hline SWITZERLAND & & 1 & & & & & & & & & & & & & & & & \\
\hline TAIWAN & & & & & & & & & & & & & & & & & & \\
\hline TURKEY & & & & & & & & & & & & & & 1 & & 4 & & \\
\hline UKRAINA & & & & & & & & & & 4 & & 4 & & & & & & 2 \\
\hline UNKNOWN & 1 & & & & & & & & & & & & 1 & & & & & 2 \\
\hline YUGOSLAVIA & & & & & & & & & & & & & & & & & & 1 \\
\hline USA & & & & & & & & & & & & & 1 & & & & & \\
\hline TOTAL & 19 & 45 & 22 & 5 & 1 & 3 & o & 9 & 42 & 7 & 14 & 6 & 14 & 11 & 1 & 12 & 4 & 105 \\
\hline
\end{tabular}

Table 2: Distribution of the 289 ex-libris with cat images per technique 


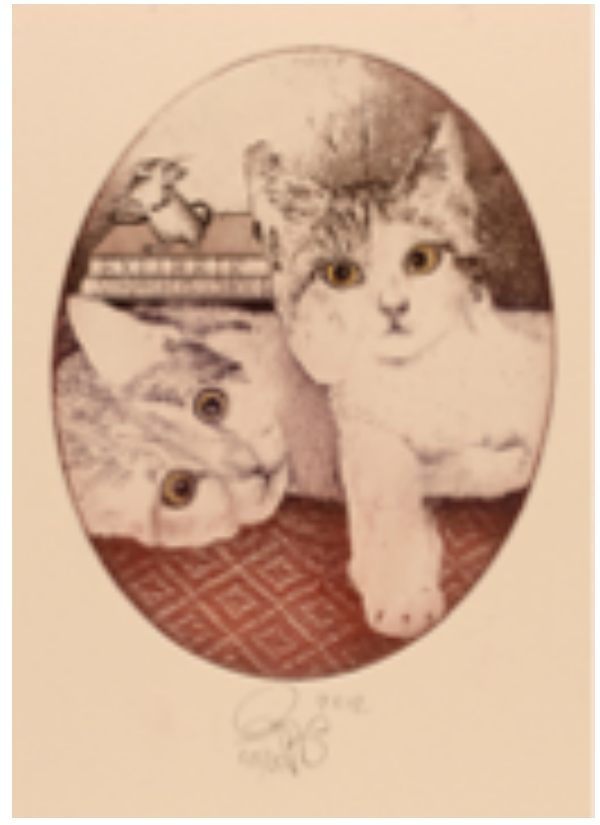

Image 4: "Anonymous" ex-libris - Germany, 2012, Olaf Gropp

\author{
$X_{5}=$ Intaglio-relief on metal \\ X6 = Engraving-relief on plastic \\ $\mathrm{C}_{2}=$ Graver engraving on copper \\ $\mathrm{C}_{3}=$ Etching \\ $\mathrm{C}_{4}=$ Drypoint \\ $\mathrm{C}_{5}=$ Aquatint \\ C7 $=$ Mezzotint \\ $\mathrm{P} 1=$ Line block \\ $\mathrm{P} 7=$ Offset \\ P8 $=$ Photograph \\ $\mathrm{CRD}=$ Computer reproduced \\ $\mathrm{T}=$ Typography, letter press
}

The 289 ex-libris with cat images were also examined according to their distribution of technique. A table was generated to show the distribution of techniques. The table indicates that wood engraving is the most popular printing technique on the ex-libris with cat images. Wood engraving is one of the oldest known printing techniques. The earliest examples are the wood engravings used as seals in Egypt and Mesopotamia. It still appears to be a popular technique. Etching follows wood engraving. An intaglio technique, etching is frequently used by engravers. Zinc, copper, aluminum or lead molds are etched with acid. The following techniques are, respectively, linocut, woodcut, aquatint and line block, computer reproduced, offset, graver engraving on copper, drypoint, mezzotint, metal engraving, typography, engraving-relief on plastic and, finally, intaglio-relief on metal and photograph.

\section{Conclusion}

In spite of the poor attitude towards cats in the medieval Europe, the distribution of cat images in ex-libris does not support such a historical connection. First of all, it would be unwise to reach such a conclusion because several eastern countries are not included in the museum's collection. Additionally, ex-libris is an art form that is popular in Europe and European countries appear to be higher in the list. It is natural that Germany ranks as the first country in cat image use because the first ex-libris example was designed and the first printing press was manufactured in Germany. The message given in an ex-libris through symbols and markings immediately reflects how the orderer is perceived by the people around him. Designs express the things the orderer places importance in his life, and the artist turns these elements into small visual artworks. Ex-libris designs indicate that book owners, designers and artists use or order ex-libris on the inner covers of their books in their library to reflect their love of books and cats. 
The distribution of printing technique in the ex-libris with cat images shows that the most frequently used technique is the oldest known one, wood engraving. This has been the most popular technique with artists.

Ex-libris designs make book owners feel special and are appreciated as a beautiful form of art as they continue to serve their function.

\section{References}

Akurgal, E. (2005). Anadolu Kültür Tarihi. Ankara: Tübitak.

Aysoy, S. (1954). Değişik Milletler Tarihlerinde Kedi. Ankara Üniversitesi Veteriner Fakültesi Dergisi, 40-66.

Erinç, S. M. (1996). Bir Sanat Dalı Olarak Exlibris. Anadolu Sanat, 69-73.

Güney, A. (2014). Anadolu'da Başlangıcından MÖ I. Binin Sonuna Kadar Hayvan Biçimli Damga Mühürler. Yüksek Lisans Tezi. Ankara: Ankara Üniversitesi, Sosyal Bilimler Enstitüsü, Arkeoloji Anabilim Dalı.

Manguel, A. (2001). Okumanın Tarihi. İstanbul: YKY.

Okur, G. (2013). Iletişim Açısından Ekslibris. Anadolu Üniversitesi Sanat \& Tasarım Dergisi, 40-48.

Pektaş, H. (2017). Ekslibris (4 ed.). İstanbul: iED.

Pektaş, H. (2017). Frederikshavn Sanat Müzesi ve Ekslibris Koleksiyonu. Exlibrist Uluslararası Ekslibris Dergisi, 129-134. 